\title{
Bovine intramammary Escherichia coli challenge infections in late gestation demonstrate a dominant antiinflammatory immunological response
}

\author{
R. R. Quesnell, ${ }^{*} \dagger$ S. Klaessig, ${ }^{\star}$ J. L. Watts, $†$ and Y. H. Schukken ${ }^{\star 1}$ \\ ${ }^{*}$ Quality Milk Production Services, College of Veterinary Medicine, Cornell University, Ithaca, NY 14853 \\ †Pfizer Animal Health, Kalamazoo, MI 49001
}

\begin{abstract}
Coliform mastitis that presents itself at parturition or in the early weeks of bovine lactation is often characterized by severe inflammation and impaired milk production and can lead to death of the animal. Chronic intramammary infections caused by persistent strains of Escherichia coli may result in high production losses. The aim of this study was to determine the inflammatory response to a teat-canal challenge of bovine mammary glands with a persistent strain of $E$. coli during late gestation (dry period) and into early lactation. Two weeks before parturition, animals were challenged in 2 quarters with $30 \mathrm{cfu}$ of a persistent strain of E. coli; control quarters were vehicle-infused and not infused, respectively. Samples of dry cow secretions were taken from all quarters before challenge and at $6,12,18,24$, 48, 72, 96, and $120 \mathrm{~h}$ following challenge. Colostrum samples and milk samples were taken from all quarters at parturition and $6,12,18,24,48,72,96$ and $120 \mathrm{~h}$ postpartum. Bacterial culture, combined with random amplified polymorphic DNA genetic strain-typing analysis, indicated recovery of the bacterial challenge strain until 48 to $96 \mathrm{~h}$ postchallenge, and again at parturition and up to 6 and $12 \mathrm{~h}$ postpartum. One animal exhibited clinical mastitis and the bacterial challenge strain was evident to at least $12 \mathrm{~d}$ postpartum. During twicedaily milkings, production levels were lower in bacteriachallenged quarters compared with controls. Somatic cell counts decreased to normal levels at a slower rate in challenged quarters compared with control quarters. Cytokine analysis indicated a minimal proinflammatory cytokine response, including interleukin-1 $\beta$ and tumor necrosis factor- $\alpha$ in challenged-quarter dry cow samples up to $120 \mathrm{~h}$ postchallenge. Interleukin-10 levels were significantly increased by $12 \mathrm{~h}$ postchallenge in secretions from challenged and control quarters. These preliminary results in 2 cows indicate that proinflam-
\end{abstract}

Received February 18, 2011.

Accepted September 12, 2011.

${ }^{1}$ Corresponding author: yschukken@cornell.edu matory signaling after intramammary bacterial infection may be actively suppressed during late gestation. We hypothesize that this immune-inhibitory response allows intramammary infections to become persistent in the dry period and cause clinical signs immediately after parturition.

Key words: coliform mastitis, interleukins, tumor necrosis factor- $\alpha$, dry period

\section{INTRODUCTION}

Clinical mastitis is one of the most common and costly challenges to the dairy industry (Todhunter et al., 1991; Barkema et al., 1998; Bradley and Green, 2001a; Gröhn et al., 2004). Great progress has been made in the prevention and treatment of mastitis resulting from many contagious pathogens, but prevention or treatment programs to address the problem of coliform mastitis have been limited. Approximately $40 \%$ of clinical mastitis cases are attributed to gram-negative, mostly coliform, bacterial infections (Bradley and Green, 2001b; Erskine et al., 2003; Gröhn et al., 2004). Coliform mastitis in dairy cows is generally considered an opportunistic infection (Burvenich et al., 2007), although evidence for a host-adapted subpopulation is growing (Bradley and Green 2001a; Green et al., 2002; Dogan et al., 2006; Shpigel et al., 2008; Almeida et al., 2011). Dairy cows may be vaccinated against coliform mastitis using a core antigen vaccine that has been reported to reduce clinical severity of response to these infections (Wilson et al., 2007, 2008). However, medicinal preventative strategies that have repeatedly been demonstrated to reduce incidence of intramammary infection are currently limited to an internal teat sealant (Bradley et al., 2011). The evolution of improved management and effective treatment programs for gram-positive and contagious mastitis infections have reduced the losses incurred within the industry, but coliform mastitis continues to be a problem that offers challenges to even the most well-managed dairies (Bradley and Green, 2001a,b). This is in part because antibiotic therapies are considered to have limited value in treating clinical or subclinical coliform mastitis (Erskine et al., 2003). 
The incidence of clinical mastitis peaks on most farms immediately following parturition (Barkema et al., 1998); however, several field studies have shown the presence of bacteria isolated from the dry gland before parturition without clear inflammatory indicators of mastitis (Todhunter et al., 1990b; Bradley and Green, 2004; Green et al., 2007). A limited inflammatory response during the dry period could reflect an adaptation in maternal immune signaling during late gestation to protect the fetus from severe proinflammatory responses and improve fetal survival chances in a genetically dissimilar maternal environment (Dietert and Piepenbrink, 2008). Although only limited data are present for dairy cows (Shafer-Weaver et al., 1999), mouse and human studies would suggest that late gestation constitutes a $\mathrm{T}$ helper-2 $\left(\mathbf{T h}_{\mathbf{2}}\right)$-biased inflammatory response period (Björkstén, 1999). This immunological bias against the $\mathrm{T}$ helper-1 $\left(\mathbf{T} \mathbf{h}_{1}\right)$ proinflammatory response might be responsible for survival of bacteria in the mammary gland upon infection in late gestation during the dry period.

As far as we know, bacterial challenges of the mammary gland during late gestation have not been published. Quantitative information on bacterial survival after challenge in late gestation would provide the missing link between the expected $\mathrm{Th}_{2}$-dominated immune response and the observed high incidence of clinical disease immediately after parturition. In addition, identifying the dominant inflammatory mediators invoked in the mammary gland upon bacterial infection during late gestation will provide a better understanding of the potential gaps in the immune response necessary for defense of the gland against bacterial invasion. It is essential to gain a better understanding of the immunological response to invasion and survival of coliform bacteria in the mammary gland during late gestation before effective treatment and prevention strategies can be developed.

Therefore, the primary goal of this study was to examine cytokine profiles in response to an intramammary challenge with a persistent strain of Escherichia coli during late gestation (late dry period), monitor the persistence of the challenge-strain in the mammary gland, and evaluate the clinical and immunological response to bacterial presence in the mammary gland during the transition to lactation after parturition.

\section{MATERIALS AND METHODS}

\section{Animal Selection and Housing}

Two cows (cows 365 and 450) were selected from the Cornell University Veterinary College Dairy herd based upon examination of mastitis history and milk SCC collected monthly. Only animals with consistently low SCC $(<200,000$ cells $/ \mathrm{mL})$ and no history of clinical mastitis in the current lactation were included in the study. The cows were in their second (cow 365) and third (cow 450) lactations at the start of the study. The cows were housed in tie-stalls and bedded on straw. Animals were fed twice daily with a diet designed specifically for energy needs during gestation and lactation as applicable. At least $3 \mathrm{~d}$ before their expected due date, the cows were moved to calving stalls and bedded in straw. Stalls were cleaned at least twice daily. Lactating cows were milked twice daily at 12 -h intervals. Milking was done using a quarter milker set up with 4 Lactocorder devices (WMB-AG, Balgach, Switzerland) to measure quarter milk production. Temperature and health status were carefully monitored at each milking and at each sampling time.

\section{Bacterial Challenge}

Thirty colony-forming units of a persistent strain of E. coli (strain C1, Dogan et al., 2006) suspended in 2 $\mathrm{mL}$ of PBS was introduced into the teat canal, below Furstenburg's rosette, of 2 contralateral quarters of each animal. A third quarter received a similar infusion of vehicle only, and the fourth quarter received no infusion.

\section{Sampling Strategy}

Samples were collected aseptically for evaluation of bacteria within the glandular secretions, and $100-\mu \mathrm{L}$ samples were plated immediately on MacConkey agar plates (VWR, Radnor, PA) and incubated overnight at $37^{\circ} \mathrm{C}$. Colonies were counted and individual colonies were isolated and stored at $-70^{\circ} \mathrm{C}$ for molecular straintyping via random amplification of polymorphic DNA (RAPD) analysis. Duplicate lacteal samples were collected from all quarters for cytokine analysis and bacterial culture 1 wk before challenge, immediately before challenge $(t=0)$, and at $6,12,18,24,48,72,96$, and $120 \mathrm{~h}$ postchallenge during the dry period. Samples were collected from all quarters for cytokine analysis, SCC, and bacterial culture at 6, 12, 18, 24, 48, 72, 96, and $120 \mathrm{~h}$ following parturition.

Clinical mastitis was determined by evaluating clinical symptoms such as abnormal milk, swelling and redness of the mammary gland, and increased body temperature. Abnormal milk was further evaluated using the California Mastitis Test and SCC. In the case of clinical mastitis, samples were collected for cytokine analysis, SCC, and bacterial culture at $6,12,18,24$, $48,72,96$, and $120 \mathrm{~h}$ following the initial diagnosis of clinical mastitis. 


\section{Dry Cow/Milk Sampling Procedure}

Nitrile gloves were worn and changed several times, if necessary, throughout the entire sampling procedure and always between cows. Teats were wiped with a dry towel to remove gross contamination. Teats were then dipped in iodine solution (Bovadine, West Agro, Kansas City, MO), and allowed a 30-s contact time. Teats were wiped dry with a clean and dry paper towel. Clean gauze $(4 \times 4$ inch $)$ soaked in $70 \%$ ethanol was used to wipe teats and then teats were allowed to dry. Teat ends were scrubbed a second time with a gauze soaked in $70 \%$ ethanol and again allow to dry. Gloves were changed and teats were stripped once, and teat contents were expressed $(1-2 \mathrm{~mL})$ into sterile sample tubes and immediately placed on ice. Quarters were massaged or squeezed if necessary to obtain sufficient material. Following sampling, teats were dipped in iodine solution (Bovidine), with at least a $30=\mathrm{s}$ contact time. Teats were then dipped in teat seal solution (Udder Gold, Ecolab, St. Paul, MN) and allowed to dry. The animals remained standing until the teat seal solution was fully dry.

\section{Whey Preparation}

Whey preparation methods were taken from Bannerman et al. (2004). Briefly, dry cow secretions, colostrum, and milk samples were centrifuged at $500 \times g$ for 15 min to remove cells. Samples were centrifuged at $40,000 \times g$ for $30 \mathrm{~min}$ at $4^{\circ} \mathrm{C}$. The fat layer was removed with a sterile wooden stick, and translucent whey was moved to another tube and maintained at $-70^{\circ} \mathrm{C}$ until cytokine analysis.

\section{Cytokine Analysis}

Ninety-six-well sample plates were prepared with a primary capture antibody for IL-1 $\beta(5 \mu \mathrm{g} / \mathrm{mL}$; Endogen, Rockford, IL) and tumor necrosis factor- $\alpha$ (TNF- $\alpha, 1$ $\mu \mathrm{g} / \mathrm{mL}$; Endogen) in a $0.5 \mathrm{M}$ carbonate coating buffer. Plates were allowed to incubate overnight at $4^{\circ} \mathrm{C}$. All plates, washes, and blocking reagents were allowed to equilibrate to room temperature. Plates were washed 5 times with wash buffer (Tris-buffered saline with Tween) and blocked with 1:10 Seablock:Tris buffered saline (Pierce, Rockford, IL) for $1 \mathrm{~h}$. Plates were washed 5 times with wash buffer. Whey samples were diluted in blocking buffer to achieve optimal quantitative analysis as determined by placement on the linear portion of the respective cytokine standard curve for each assay. Recombinant proteins for respective cytokines were diluted to appropriate concentrations and included as a standard curve for each assay. Then, $100-\mu \mathrm{L}$ aliquots of standards and samples were incubated at room temper- ature $\left(22^{\circ} \mathrm{C}\right)$ for $2 \mathrm{~h}$. Plates were washed 5 times with wash buffer. Biotin-labeled secondary antibodies IL-1 $\beta$ $(5 \mu \mathrm{g} / \mathrm{mL}$; Endogen $)$ and TNF- $\alpha(5 \mu \mathrm{g} / \mathrm{mL}$; Serotec, Raleigh, NC) were added to the wells $(100 \mu \mathrm{L} /$ well $)$. Plates were incubated for $1 \mathrm{~h}$ at room temperature in the dark. Plates were washed 5 times in wash buffer, and then streptavadin:horseradish peroxidase complex diluted 1:1000 in blocking buffer was added to wells $(100 \mu \mathrm{L} /$ well $)$ and incubated in the dark for $1 \mathrm{~h}$ at room temperature $\left(22^{\circ} \mathrm{C}\right)$. Plates were washed 5 times in wash buffer and $100 \mu \mathrm{L}$ of tetramethylbenzidine was added to each well. Plates were incubated for 10 to 25 min at room temperature in the dark, and $100 \mu \mathrm{L}$ of 2 $M \mathrm{H}_{2} \mathrm{SO}_{4}$ was added to each well. Plates were analyzed on a Fluoroskan II Fluorescent plate reader (Thermo,

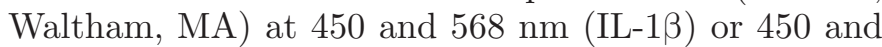
$650 \mathrm{~nm}(\mathrm{TNF}-\alpha)$.

\section{RAPD Strain Typing}

Individual isolates from bacterial culture plates were grown in Luria-Bertani broth at $37^{\circ} \mathrm{C}$ for $12 \mathrm{~h}$. The broth was removed and bacteria were rinsed 3 times with PBS. Then, DNA was isolated from samples using QiaShredder tubes and QiaQuick DNAeasy isolation kit (Qiagen, Valencia, CA). The quality of the DNA was confirmed with an Agilent BioAnalyzer, and PCR was performed using GoTaq Green Master Mix (Promega, Madison, WI). The primers were designed specifically for RAPD typing of gram-negative species, resulting in the following primers: forward 5'-AGTAAGTGACTGGGGTGAGCG-3' and reverse 5'-TACATTCGAGGACCCCTAAGTG-3'. These primers have been shown to discriminate between mastitis E. coli bacterial strains (Dogan et al., 2006). The PCR products were evaluated using gel electrophoresis in a $1.5 \%$ agarose gel at $60 \mathrm{~V}$ for $1.5 \mathrm{~h}$.

\section{Data Analysis}

Results were analyzed using SAS software (SAS Institute Inc., Cary, NC). Data are presented as mean \pm SEM. The difference between control and challenged quarters was analyzed using ANOVA and Student's $t$-test. Differences in cytokine values before and after challenge were analyzed using the nonparametric Wilcoxon rank sum test. Differences were considered statistically significant when the probability of a type I error was $<0.05$.

\section{RESULTS}

\section{Bacterial Cultures Postchallenge and Postparturition}

Actual infused colony-forming units of the $\mathrm{C} 1$ challenge strain were $30 \pm 2 \mathrm{cfu}$ in challenged quarters for 

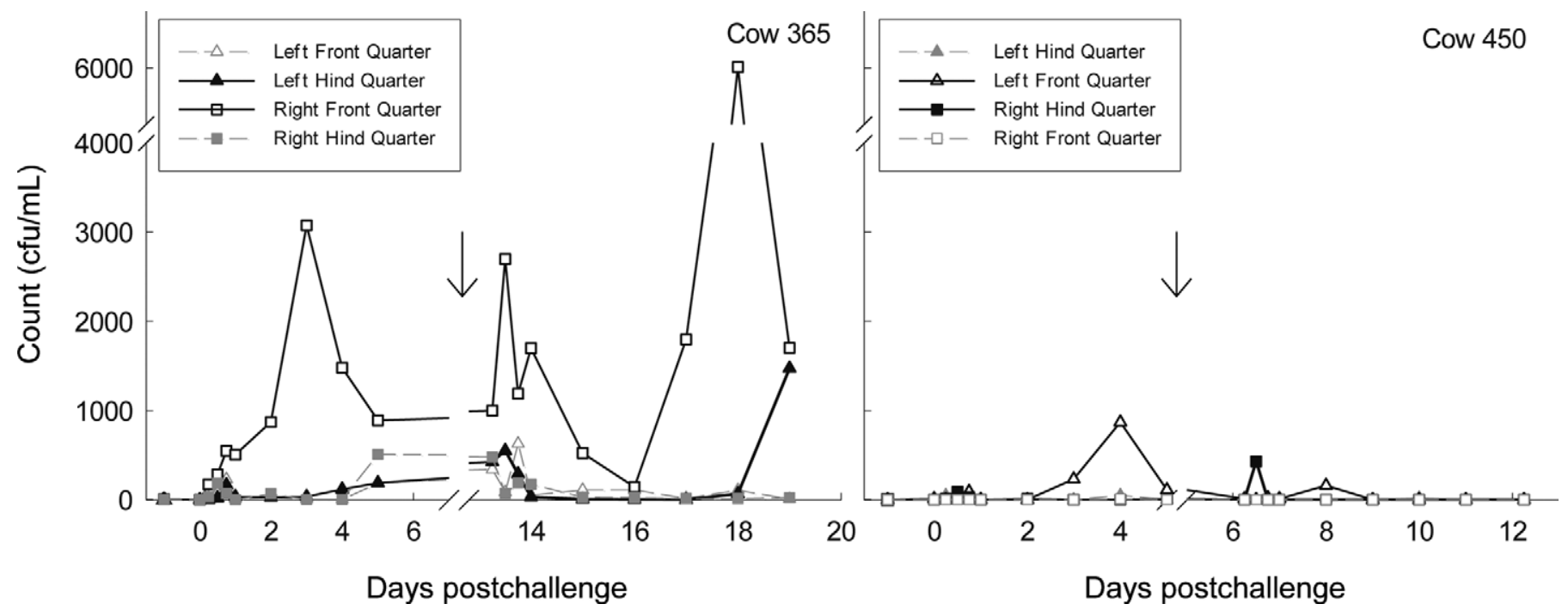

Figure 1. Bacterial culture results expressed as colony-forming units postchallenge and postparturition. Results are shown for cow 365 (left panel) and cow 450 (right panel). Results for challenged quarters are presented as black lines, and those for control quarters are shown as dashedgray lines. Arrows indicate the time of calving.

cow 450 , and $32 \pm 5$ cfu in challenged quarters for cow 365. Bacteria were recovered from dry cow secretions in both cows for 48 to $96 \mathrm{~h}$ postchallenge and from milk samples at parturition and up to $12 \mathrm{~h}$ postparturition (Figure 1). In Figure 1, all colony-forming units identified in milk samples in all quarters are reported. The challenge strain was never identified in the nonchallenged quarters. No clinical evidence of inflammatory responses was observed in response to bacterial challenge immediately after challenge and during the remaining of the dry period. One animal (365) demon- strated signs of clinical mastitis in the challenged right front quarter from 9 to $12 \mathrm{~d}$ postpartum, which also resulted in a fever spike (Figure 2). Higher bacterial counts and SCC were evident in the affected quarter on those days (Figures 1 and 3). The RAPD method for bacterial strain discernment was optimized to ensure adequate evaluation and discernment with our C1 strain. Control DNA samples were isolated from the original challenge strain at the same time DNA was harvested from recovered sample colonies to provide an accurate comparison. The RAPD results indicated that
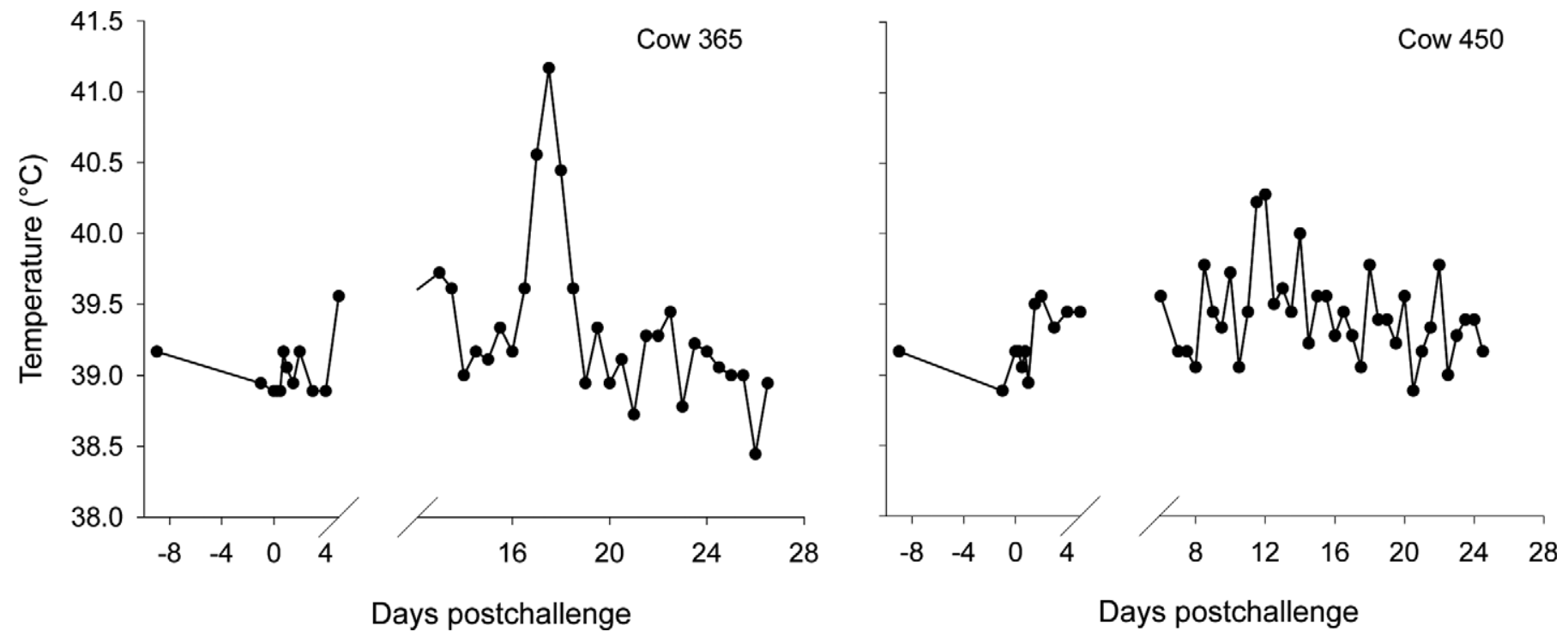

Figure 2. Body temperature before and after challenge and after calving for cow 365 (left panel) and cow 450 (right panel). 
the $\mathrm{C} 1$ chronic E. coli strain was present in the gland for at least 48 to $96 \mathrm{~h}$ postchallenge. The $\mathrm{C} 1$ challenge strain was observed again at parturition and for at least 6 to $12 \mathrm{~h}$ postpartum (Figure 4). Additionally, RAPD analysis confirmed the presence of the $\mathrm{C} 1$ challenge strain at $12 \mathrm{~d}$ postcalving in the right front quarter from the animal (cow 365) that demonstrated signs of clinical mastitis (Figure 4).

\section{Clinical and Immunological Response to Challenge}

Calving was at $13 \mathrm{~d}$ postchallenge for cow 365 and 7 d postchallenge for cow 450. Somatic cell counts were elevated in early milk samples from quarters challenged with the $\mathrm{C} 1$ chronic $E$. coli strain (Figure $3 ; P<0.05$ ). Somatic cell counts in challenged quarters declined to values near that of control quarters within 3 to $4 \mathrm{~d}$ postcalving, except in one quarter in which clinical mastitis was evident (right front quarter of cow 365 ) 9 to $12 \mathrm{~d}$ postcalving.

Body temperature did not increase immediately postchallenge in either animal, although a slight elevation in temperature was evident in both animals immediately before and following parturition (Figure 2).
Interestingly, a more pronounced increase in temperature was observed 7 to $12 \mathrm{~d}$ postcalving in both cows, which returned to previous postcalving levels within 48 h. No indications of clinical mastitis were evident in cow 450 during the period of elevated temperature. Coinciding with the highest temperature spike, the right front quarter of cow 365 demonstrated clinical signs of mastitis, high SCC, and bacterial recovery of the C1 challenge strain.

Milk production was lower in challenged quarters compared with control quarters in both animals $(P<$ 0.01; Figure 3). Milk weights from all challenged quarters were pooled at each milking time point, and pooled milk weights from unchallenged or control quarters were compared at each milking, revealing a striking decrease of $5 \mathrm{~kg} / \mathrm{d}( \pm 1.9)$ in overall daily milk production in 4 challenged quarters compared with 4 controls $(P<$ $0.05)$.

The proinflammatory cytokines IL- $1 \beta$ and TNF- $\alpha$ (Figure 5) were not significantly elevated after E. coli bacterial challenge during the dry period (Wilcoxon rank sum test; $P>0.5$ ). After parturition, proinflammatory cytokine levels (particularly IL-1 $\beta$ and TNF- $\alpha$ ) were elevated in challenged quarters only at the time
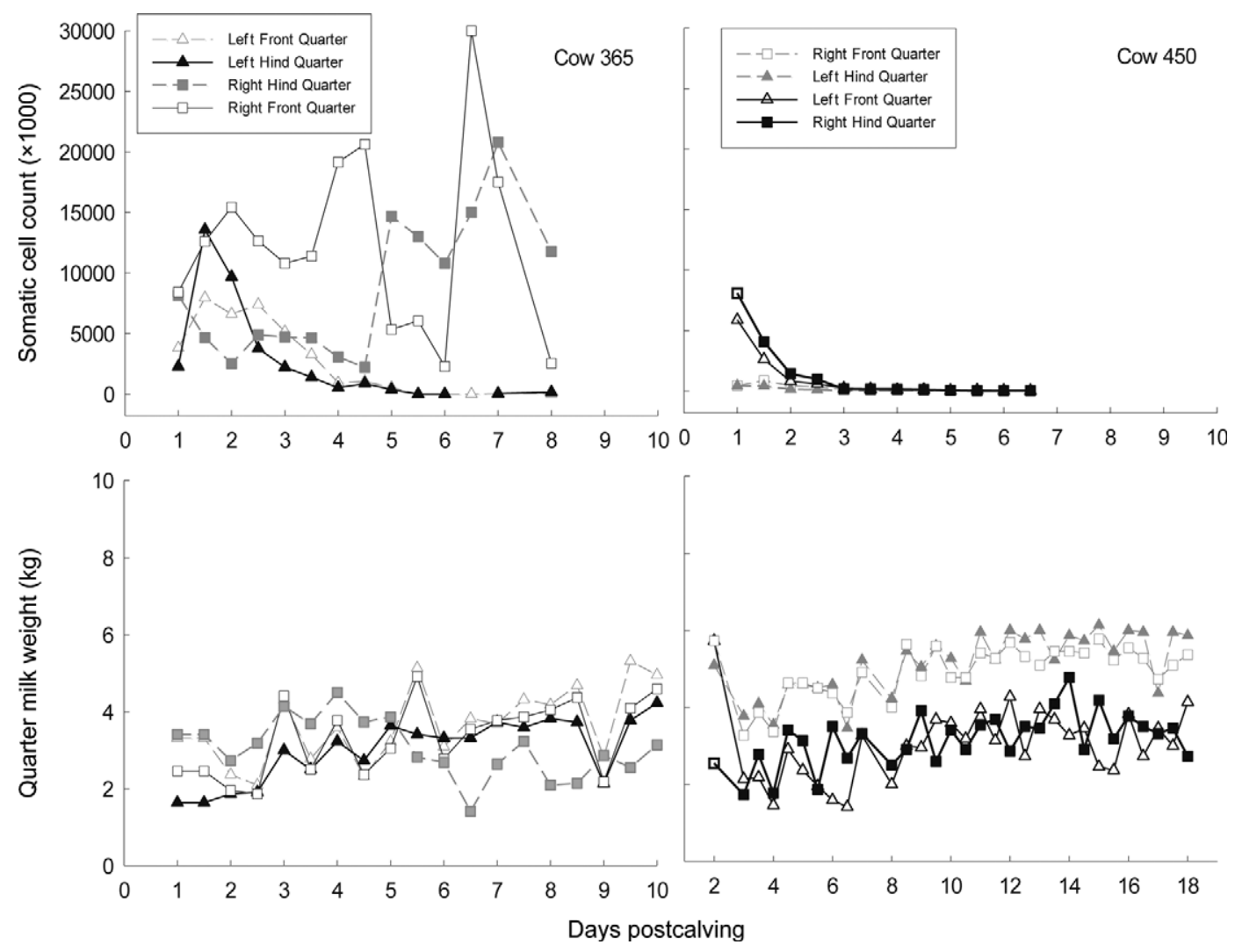

Figure 3. Somatic cell counts and milk production per quarter in 2 infected and 2 control quarters. Results for challenged quarters are presented as black lines, and those for control quarters are shown as dashed-gray lines. 


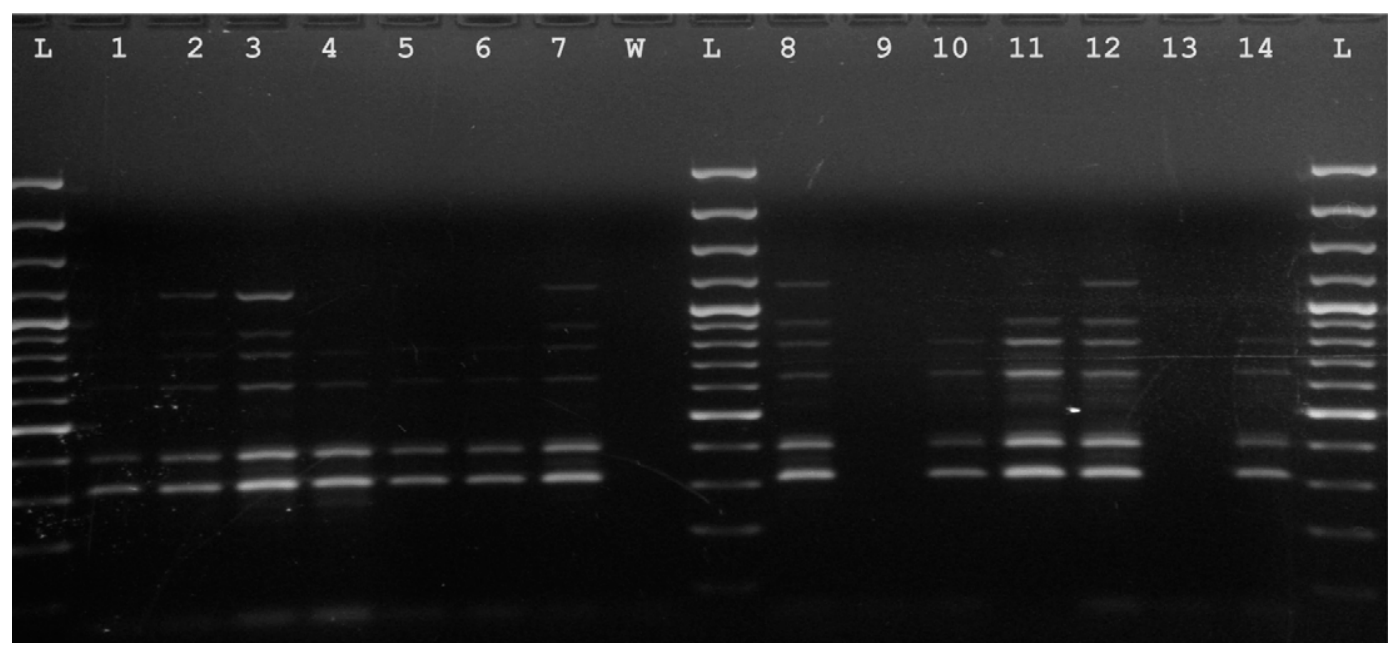

Figure 4. Random amplified polymorphic DNA strain typing of recovered bacterial isolates. $\mathrm{L}=$ molecular weight ladder; $\mathrm{W}=$ water control; lanes 1 and 8 are challenge strains C1 from challenge fluid; lanes 2 to 7 are from isolates isolated from cow 365, lanes 9-14 are from cow 450; lanes 2 to 4 are isolates from samples taken at 6,24 , and $48 \mathrm{~h}$ postchallenge; lanes 5 and 6 are isolates from samples taken at $6 \mathrm{~h}$ and $12 \mathrm{~d}$ postpartum; lane 7 is from an isolate recovered at the time of clinical mastitis; lanes 9 to 11 are from samples at 6,12 , and $18 \mathrm{~h}$ postchallenge; lanes 12 to 14 are from postpartum samples at 6,12 , and $18 \mathrm{~h}$.

of clinical mastitis in cow 365, when we also observed an elevation in temperature and SCC and were able to recover the challenge strain from the affected gland.

Relative levels of the antiinflammatory cytokine IL10 were elevated approximately 3.5 -fold $(349 \pm 52 \%)$ within 12-h postchallenge (Figure 6). Levels of IL-10 postchallenge were significantly higher in both cows compared with the prechallenge level (Wilcoxon rank sum; $P<0.03)$. The IL-10 levels were elevated to a similar extent in all quarters, both challenged and control quarters.

\section{DISCUSSION}

This initial study sought to determine bacterial survival and the immediate inflammatory response after an intramammary E. coli bacterial challenge during late gestation. Furthermore, persistent bacterial presence and clinical and immunological responses to bacterial presence were evaluated during the transition to lactation after calving and during early lactation. Our results confirm the suggestion from observational studies (Bradley and Green, 2001b, 2004; Green et al., 2002) that mammary glands may become infected during late gestation, harbor infection during the remainder of the dry period without mounting an inflammatory response, and only show clinical mastitis in the postparturition period.

When a cow is challenged in early lactation, the innate immune response to coliform mastitis in the bovine mammary gland would be expected to be rapid acting and play a protective role in the gland when confronted with a gram-negative bacterial challenge (Burvenich et al., 2007; Bannerman, 2009). The many cellular components and signaling mechanisms involved in modulating the body's response to gram-negative bacterial invasion often lead to a systemic inflammatory response (van Amersfoort et al., 2003), which in dairy cows includes more or less severe symptoms of clinical mastitis (Burvenich et al., 2007). In contrast to these findings from bacterial challenges during lactation, we observed no discernable clinical response to bacterial challenge of the mammary gland in late gestation with E. coli bacteria. Also in these late gestation cows, no proinflammatory cytokine response after bacterial challenge was found as was observed after $E$. coli challenge in lactation (Bannerman et al., 2004).

Systemic responses include fever, inflammation, and potential shock response during late gestation. Maternal $\mathrm{Th}_{1}$-type immunity, resulting in increases in cytokines such as IFN- $\gamma$ and TNF- $\alpha$, has been shown to be hazardous to fetal development (Raghupathy, 1997). Hence, physiological difficulties could arise for both the mother and the offspring and suggest that the animal and offspring are protected from an inflammatory compromise by a natural response during late gestation to inhibit the proinflammatory cytokines via an IL-10 mediated, potentially $\mathrm{Th}_{2}$-biased immunological response (Raghupathy and Kalinka, 2008).

Bacterial persistence during the dry period, without obvious signs of inflammation, suggested successful bacterial adhesion and possible cellular invasion during the dry period compared with lactation (Dogan et al., 2006; Almeida et al., 2011). Differences between adher- 

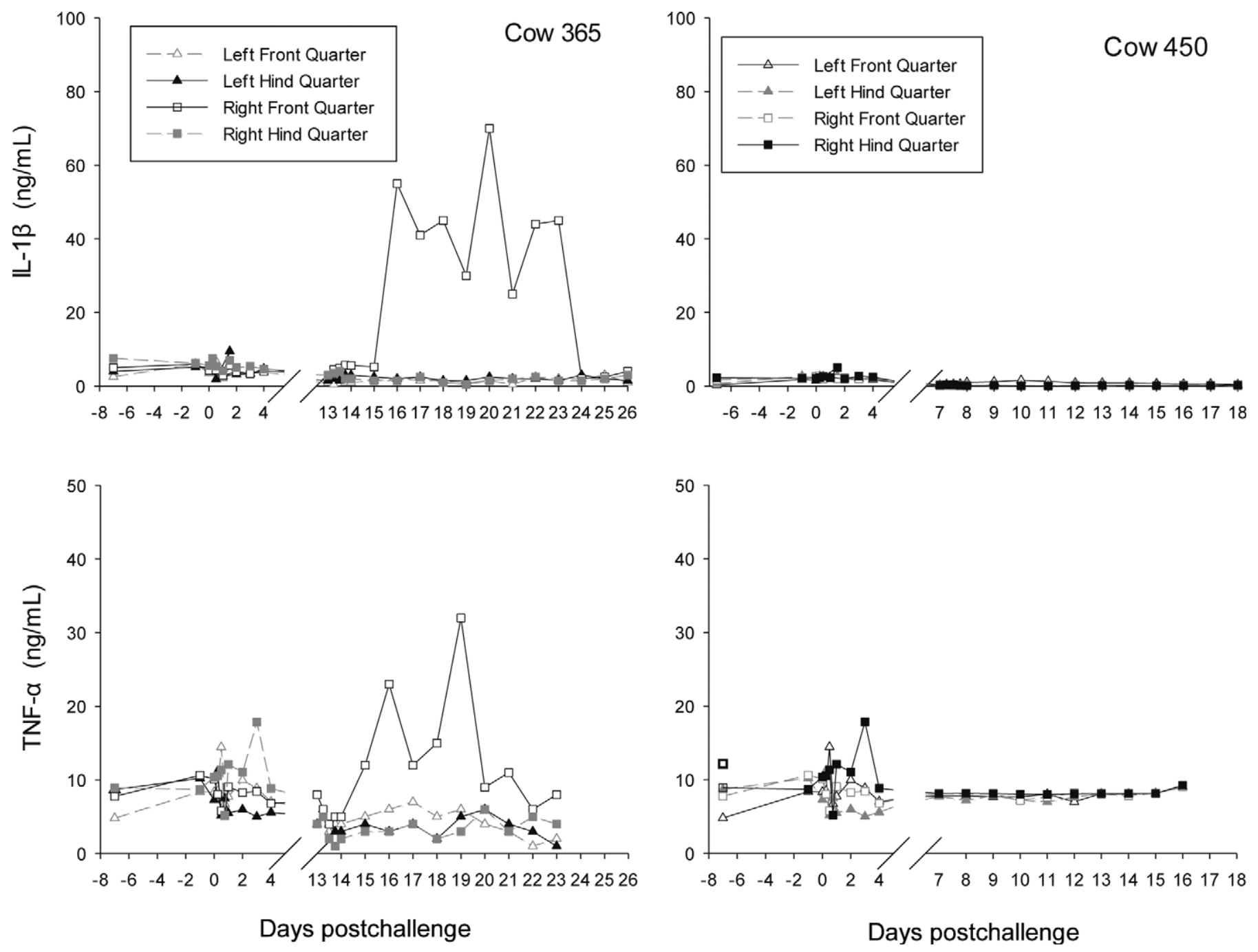

Figure 5. Concentrations of proinflammatory cytokines in dry period secretum and milk before and after challenge infection and postparturition. Results for IL-1 $\beta$ and tumor necrosis factor (TNF)- $\alpha$ are presented for cow 365 (left panel) and cow 450 (right panel). Results for challenged quarters are presented as black lines, and those for control quarters are shown as dashed-gray lines. Calving was at $13 \mathrm{~d}$ postchallenge for cow 365 and $7 \mathrm{~d}$ postchallenge for cow 450 .

ence and invasion capacity have been closely examined in common gram-positive mastitis bacteria, including various streptococcal and staphylococcal species in cultured epithelial cells (Hensen et al., 2000). Additionally, strains of $E$. coli associated with persistent coliform mastitis have an enhanced ability to adhere, invade, and survive in cultured mammary epithelial cells compared with strains causing transient infections (Dogan et al., 2006; Passey et al., 2008; White et al., 2010). In this challenge study, we used strain C1, described by Dogan et al. (2006), because this strain has been proven to possess invasive capabilities in vitro.

Results of our challenge study indicated a significant increase in IL-10, suggesting an inhibitory inflammatory response to $E$. coli challenge during the dry period, with a complete absence of a proinflammatory cytokine response. This raises the possibility of a $\mathrm{Th}_{2}$-biased immunological response during late gestation in the dairy cow's dry period. Inflammatory cytokine responses, including IL- $1 \beta$ and TNF- $\alpha$, were evident postpartum, and IL-10 levels were lower than during the dry period, indicating a reversal to $\mathrm{Th}_{1}$ dominance after parturition (Taylor et al., 2006).

The observations in 2 challenged cows would suggest that clinical response to bacterial challenge during the dry period is considerably different than a similar challenge during lactation (see, for example, challenge studies by Bannerman et al., 2004; Hogan et al., 2005; Wilson et al., 2007). It has been suggested that the metabolic changes that occur in the last few weeks of 

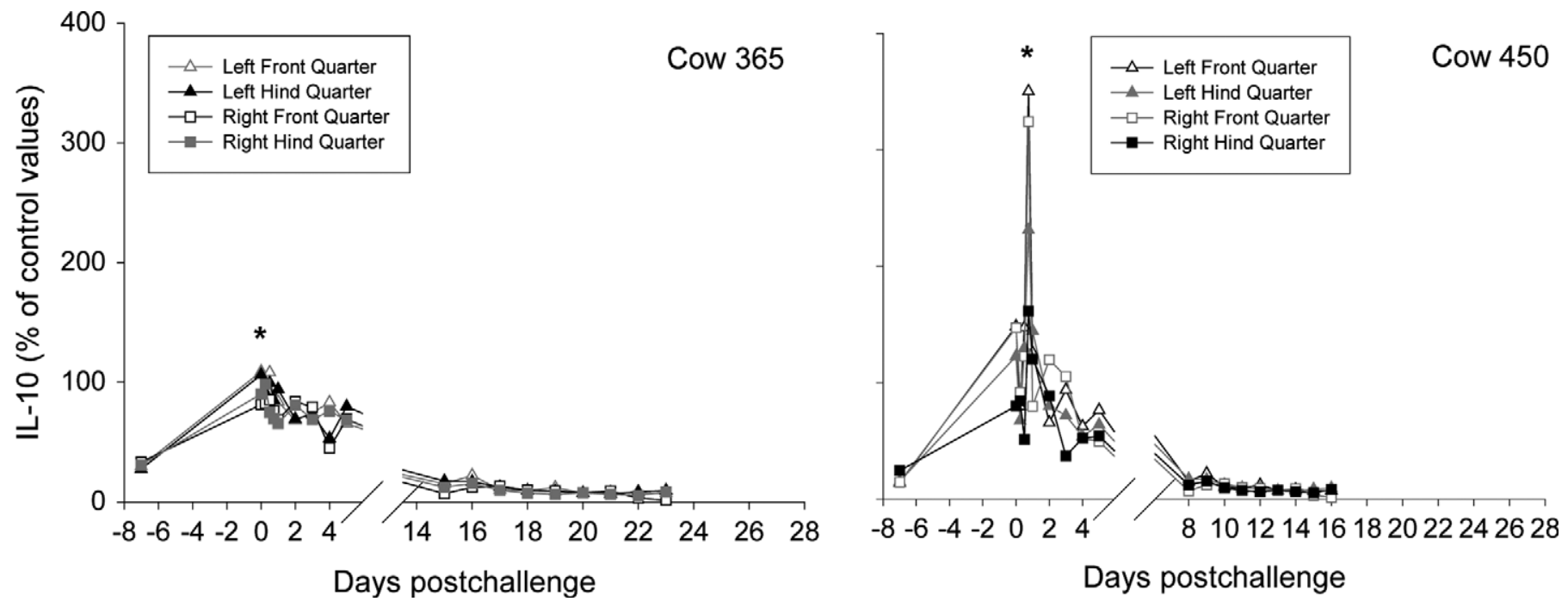

Figure 6. Concentrations of antiinflammatory IL-10 cytokine in dry period secretions and milk before and after challenge infection and postparturition. Results are shown for cow 365 (left panel) and cow 450 (right panel). Results for challenged quarters are presented as black lines, and those for control quarters are shown as dashed-gray lines. Statistical significance is indicated with an asterisk $(*)$.

the dry period and throughout the transition to lactation challenge the metabolic balance of the animal, leading to increased susceptibility to intramammary infections (Goff, 2006). Many of the intramammary infections experienced at parturition and within the first 60 to $70 \mathrm{~d}$ of lactation demonstrate severe inflammation and even sepsis (Wenz et al., 2001; Burvenich et al., 2007). Later in lactation, the inflammatory response is reported to be more moderate (Burvenich et al., 2007). The link between metabolic compromise of the immune system and increased incidence of mastitis at parturition has been suggested (Burvenich et al., 2007); however, the physiological nature of the changes in immune status in the dry period compared with lactation is not well established. The results presented here suggest a contribution of immune status, separate from metabolic challenge, to the inflammatory response as a shift to $\mathrm{Th}_{2}$ - rather than $\mathrm{Th}_{1}$-dominated immunological response within the gland during late gestation, parturition, and early lactation (Shafer-Weaver et al., 1999).

The measured indicators of SCC and milk production over the first few weeks of lactation demonstrate that exposure to coliform bacteria during the dry period affects the milk quality and productivity of the gland over the entire period measured during early lactation (Figure 3). This reflects the in vivo observations that include reduced milk production throughout lactation being predicted by high SCC early in lactation (De Vliegher et al., 2004, 2005). Again, critical management strategies during the dry period to minimize gland exposure to these gram-negative bacteria are an important tool for improved milk quality and increased overall production (Green et al., 2007).

The persistence of bacteria within the gland reflects field observations that indicate the persistent presence of bacteria isolated from the dry gland before parturition (Bradley and Green, 2004; Green et al., 2007). Without clear inflammatory indicators of gland infectivity in the dry period, bacterial invasion of the gland might not be recognized until parturition, thus supporting the observation that the incidence of mastitis is greatly increased immediately following parturition (Barkema et al., 1998). Based on the experiments in this report, we would argue that a proportion of the spike of clinical mastitis postpartum is not due to new IMI immediately following parturition but merely the inflammatory response to IMI that occur before calving. To be able to cause clinical mastitis, the infectious organism would need to survive in the mammary gland during the dry period (Todhunter et al., 1990a,b). It has been argued that an intracellular reservoir is essential for $E$. coli to allow a persistent IMI (Passey et al., 2008; White et al., 2010). The dominant inflammatory mediators during the dry period appear to favor an antiinflammatory immune response, thus affecting the defense of the gland against bacterial invasion. The elevated levels of antiinflammatory signaling mechanisms may explain the lack of pro-inflammatory cytokine response during the dry period. The shift to a $\mathrm{Th}_{1}$-dominated inflammatory response after parturition as the gland supports lactation presents the possibility of the immune system necessitating a rapid response to an already established 
bacterial colonization. This information provides guidance with respect to the need for earlier identification of bacterial invasion and timing of potential treatment strategies, and emphasizes the importance of optimizing dry cow management strategies that prevent exposure to bacteria.

The cytokine responses to persistent E. coli strain challenge in these 2 cows during the dry period indicated an increase in IL-10 antiinflammatory response, with very little, if any, proinflammatory cytokine response. The persistence of the challenge-strain bacteria within the gland indicates local colonization in the mammary gland. At this point, we have no evidence of the localization of the surviving bacteria in the gland itself or within mammary epithelial cells (Passey et al., 2008). Interestingly, the later dry period samples consistently lacked bacterial recovery, but the challenge strain was again recovered at parturition and within $12 \mathrm{~h}$ of parturition. The analysis of SCC and milk production in early lactation suggests additional changes, perhaps to the epithelial integrity and secretory capacity, as would be expected with bacterial colonization, even in the absence of obvious inflammation. The results from the challenge study in 2 cows provide preliminary evidence of a $\mathrm{Th}_{2}$-dominant phase during the dry period and a shift to $\mathrm{Th}_{1}$-dominance after parturition. Clearly, further examination as to the modulation of the $\mathrm{Th}_{1} / \mathrm{Th}_{2}$ response during late gestation in dairy cows is required. However, these initial results suggest mechanisms that could be targeted to modulate responses to bacterial infection during the dry period and in the transition to a lactating gland.

\section{ACKNOWLEDGMENTS}

The authors thank Belgin Dogan (Cornell University, Ithaca, NY) and Ruth Zadoks (Moredun Research Institute, Midlothian, UK) for their assistance with molecular diagnostic techniques and for providing the RAPD primers for identification of recovered bacterial strain-types. This work was financially supported by Pfizer Animal Health (New York, NY).

\section{REFERENCES}

Almeida, R. A., B. Dogan, S. Klaessig, Y. H. Schukken, and S. P. Oliver. 2011. Intracellular fate of strains of Escherichia coli isolated from dairy cows with acute or chronic mastitis. Vet. Res. Commun. 35:89-101.

Bannerman, D. D. 2009. Pathogen-dependent induction of cytokines and other soluble inflammatory mediators during intramammary infection of dairy cows. J. Anim. Sci. 87:10-25.

Bannerman, D. D., M. J. Paape, J. W. Lee, X. Zhao, J. C. Hope, and P. Rainard. 2004. Escherichia coli and Staphylococcus aureus elicit differential innate immune responses following intramammary infection. Clin. Diagn. Lab. Immunol. 11:463-472.
Barkema, H. W., Y. H. Schukken, T. J. G. M. Lam, M. L. Beiboer, H. W. Wilmink, G. Benedictus, and A. Brand. 1998. Incidence of clinical mastitis in dairy herds grouped in three categories by bulk milk somatic cell counts. J. Dairy Sci. 81:411-419.

Björkstén, B. J. 1999. The intrauterine and postnatal environments. J. Allergy Clin. Immunol. 104:1119-1127.

Bradley, A. J., J. E. Breen, B. Payne, and M. J. Green. 2011. A comparison of broad-spectrum and narrow-spectrum dry cow therapy used alone and in combination with a teat sealant. J. Dairy Sci. 94:692-704.

Bradley, A. J., and M. J. Green. 2001a. Adaptation of Escherichia coli to the bovine mammary gland. J. Clin. Microbiol. 39:1845-1849.

Bradley, A. J., and M. J. Green. 2001b. Aetiology of clinical mastitis in six Somerset dairy herds. Vet. Rec. 148:683-686.

Bradley, A. J., and M. J. Green. 2004. The importance of the nonlactating period in the epidemiology of intramammary infection and strategies for prevention. Vet. Clin. North Am. Food Anim. Pract. 20:547-568.

Burvenich, C., D. D. Bannerman, J. D. Lippolis, L. Peelman, B. J. Nonnecke, M. E. Kehrli Jr., and M. J. Paape. 2007. Cumulative physiological events influence the inflammatory response of the bovine udder to Escherichia coli infections during the transition period. J. Dairy Sci. 90(E. Suppl. 1):E39-E54.

De Vliegher, S., H. W. Barkema, H. Stryhn, G. Opsomer, and A. deKruif. 2004. Impact of early lactation somatic cell count in heifers on somatic cell counts over the first lactation. J. Dairy Sci. $87: 3672-3682$

De Vliegher, S., H. W. Barkema, H. Stryhn, G. Opsomer, and A. deKruif. 2005. Impact of early lactation somatic cell count in heifers on milk yield over the first lactation. J. Dairy Sci. 88:938-947.

Dietert, R. R., and M. S. Piepenbrink. 2008. The managed immune system: Protecting the womb to delay the tomb. Hum. Exp. Toxicol. 27:129-134.

Dogan, B., S. Klaessig, M. Rishniw, R. A. Almeida, S. P. Oliver, K. Simpson, and Y. H. Schukken. 2006. Adherent and invasive Escherichia coli are associated with persistent bovine mastitis. Vet. Microbiol. 116:270-282.

Erskine, R. J., S. Wagner, and F. J. DeGraves. 2003. Mastitis therapy and pharmacology. Vet. Clin. North Am. Food Anim. Pract. 19:109-138.

Goff, J. P. 2006. Major advances in our understanding of nutritional influences on bovine health. J. Dairy Sci. 89:1292-1301.

Green, M. J., A. J. Bradley, G. F. Medley, and W. J. Browne. 2007. Cow, farm, and management factors during the dry period that determine the rate of clinical mastitis after calving. J. Dairy Sci. 90:3764-3776.

Green, M. J., L. E. Green, G. F. Medley, Y. H. Schukken, and A. J. Bradley. 2002. Influence of dry period bacterial intramammary infection on clinical mastitis in dairy cows. J. Dairy Sci. 85:25892599

Gröhn, Y. T., D. J. Wilson, R. N. González, J. A. Hertl, H. Schulte, G. J. Bennett, and Y. H. Schukken. 2004. Effect of pathogenspecific clinical mastitis on milk yield in dairy cows. J. Dairy Sci. $87: 3358-3374$.

Hensen, S. M., M. J. Pavicić, J. A. Lohuis, and B. Poutrel. 2000. Use of bovine primary mammary epithelial cells for the comparison of adherence and invasion ability of Staphylococcus aureus strains. J. Dairy Sci. 83:418-429.

Hogan, J. S., V. B. Cannon, K. L. Smith, C. Rinehart, and S. Miller. 2005. Effects of adjuvants on safety and efficacy of an Escherichia coli J5 bacterin. J. Dairy Sci. 88:534-542.

Passey, S., A. Bradley, and H. Mellor. 2008. Escherichia coli isolated from bovine mastitis invade mammary cells by a modified endocytic pathway. Vet. Microbiol. 130:151-164.

Raghupathy, R. 1997. Th1-type immunity is incompatible with successful pregnancy. Immunol. Today 18:478-482.

Raghupathy, R., and J. Kalinka. 2008. Cytokine imbalance in pregnancy complications and its modulation. Front. Biosci. 13:985-994.

Shafer-Weaver, K. A. C. M. Corl, and L. M. Sordillo. 1999. Shifts in bovine CD4+ subpopulations increase T-helper-2 compared with 
T-helper-1 effector cells during the postpartum period. J. Dairy Sci. 82:1696-1706.

Shpigel, N. Y., S. Elazar, and I. Rosenshine. 2008. Mammary pathogenic Escherichia coli. Curr. Opin. Microbiol. 11:60-65.

Taylor, A., J. Verhagen, K. Blaser, M. Akdis, and C. A. Akdis. 2006. Mechanisms of immune suppression by interleukin-10 and transforming growth factor-beta: The role of $\mathrm{T}$ regulatory cells. Immunology 117:433-442.

Todhunter, D. A., K. L. Smith, and J. S. Hogan. 1990a. Growth of gram-negative bacteria in dry cow secretion. J. Dairy Sci. 73:363372

Todhunter, D. A., K. L. Smith, and J. S. Hogan. 1990b. Intramammary challenge of the bovine mammary gland with coliform bacteria during early involution. J. Dairy Sci. 73:1217-1224.

Todhunter, D. A., K. L. Smith, J. S. Hogan, and P. S. Schoenberger. 1991. Gram-negative bacterial infections of the mammary gland in cows. Am. J. Vet. Res. 52:184-188.

van Amersfoort, E. S., T. J. Van Berkel, and J. Kuiper. 2003. Receptors, mediators, and mechanisms involved in bacterial sepsis and septic shock. Clin. Microbiol. Rev. 16:379-414.
Wenz, J. R., G. M. Barrington, F. B. Garry, K. D. McSweeney, R. P. Dinsmore, G. Goodell, and R. J. Callan. 2001. Bacteremia associated with naturally occurring acute coliform mastitis in dairy cows. J. Am. Vet. Med. Assoc. 219:976-981.

White, L. J., Y. H. Schukken, B. Dogan, L. Green, D. Döpfer, M. J. Chappell, and G. F. Medley. 2010. Modelling the dynamics of intramammary E. coli infections in dairy cows: Understanding mechanisms that distinguish transient from persistent infections. Vet. Res. 41:13-27.

Wilson, D. J., Y. T. Gröhn, G. J. Bennett, R. N. González, Y. H. Schukken, and J. Spatz. 2008. Milk production change following clinical mastitis and reproductive performance compared among J5 vaccinated and control dairy cattle. J. Dairy Sci. 91:3869-3879.

Wilson, D. J., B. A. Mallard, J. L. Burton, Y. H. Schukken, and Y. T. Gröhn. 2007. Milk and serum J5-specific antibody responses, milk production change, and clinical effects following intramammary Escherichia coli challenge for J5 vaccinate and control cows. Clin. Vaccine Immunol. 14:693-699. 